\title{
Blended Learning as An Alternative of Entrepreneurship Learning Design in The Period of Covid 19 Pandemic
}

\author{
Qurota Yunus Syafidah ${ }^{1}$, Trisno Martono ${ }^{2}$, Khresna Bayu Sangka ${ }^{3}$
}

Magister Pendidikan Ekonomi, Universitas Sebelas Maret Surakarta, Indonesia

\section{Article Info}

Volume 7, Issue 2

Page Number: 15-23

Publication Issue :

March-April-2021

\section{Article History}

Accepted : 01 March 2021

Published : 05 March 2021

\section{ABSTRACT}

The Covid 19 pandemic has had a major impact in various aspects of life including education in Indonesia. The learning process in schools has undergone various changes, including the entrepreneurial learning design used in the classroom. Therefore, a more effective and efficient entrepreneurship learning design is needed that can hinder the spread of Covid 19 in the school environment. The research method used was development research model. The results showed that the Blended Learning design was an alternative learning design that can be implemented in entrepreneurship learning. Blended learning is a combination of distance learning with online learning resources. This design was effectively and efficiently used in entrepreneurship learning during the Covid 19 pandemic. Because entrepreneurship learning is not only classroomoriented, but also requires field practice that aims to develop students' life skills in the world of work.

Keywords : Blended Learning, Entrepreneurship Learning, Covid 19 Pandemic

\section{INTRODUCTION}

Based on the Circular of the Minister of Education Number 4 of 2020, regarding the Implementation of Education in the Covid 19 Emergency, there are three policy points related to online learning. First, online learning must provide a meaningful experience, without being burdened by demands to complete all the achievements of the class promotion curriculum and school graduation. Second, online learning can be focused on life skills education. Third, learning activities and assignments may vary between students, according to their respective interests and conditions, including considering the gaps in the access or learning facilities at home.

The implementation of this policy is influenced by the readiness of various supporting factors in the learning process in schools. First, the central government must ensure the provision of fast and stable internet connection, subsidized quotas, digital equipment assistance, and increased digital capacity. Second, school capacity depends on the capital owned by schools such as infrastructure that supports online learning operations. Third, the parental participation is important to the successful of online learning. Fourth, the creativity of teachers in 
designing online learning for students has a very important role. However, in its implementation at schools there are various new problems in the online learning process, both at the Elementary Level and the Senior High Level.

One of the weaknesses of online learning at schools is the lack of student involvement. The lack of student involvement can be seen from the resilience in taking full online learning from the beginning to the end of learning (Anugrahana, 2020). The online learning system also has a negative impact on the entrepreneurial learning process at schools. Because entrepreneurship learning is not only theoryoriented subjects in the classroom, but there are practices in the learning process. This is because the goal of entrepreneurship learning is to train students to have the skills needed in the world of work. However, since the Covid19 pandemic, entrepreneurship learning activities have not run optimally because of the online learning system. This situation further adds to the problems in entrepreneurship learning so that it hinders the learning objectives itself. Because so far, the learning from home program still raises pros and cons in its implementation.

On the other hand, students' interest and motivation in learning entrepreneurship in the classroom is still low. This is influenced by the mindset of students who still think that entrepreneurship is not too important for them (Jailani et al., 2017). This further adds to the problem of entrepreneurship learning during the Covid 19 Pandemic. Therefore, an innovative and effective online learning design is needed in entrepreneurship subjects at schools. Because basically online learning systems can provide opportunities for teachers to design technology-based entrepreneurship learning that suits student needs. One of them is through blended learning design in entrepreneurship learning.
The existence of new technological discoveries has become one of the factors supporting the increasing need for the education system in Indonesia during the Covid 19 pandemic. Several innovations exist to meet the needs of teachers and students in learning, including in entrepreneurship subjects. The higher human mobility and the emergence of new technology are the background of the blended learning design as a new innovation in responding the challenges in the online learning process during the Covid 19 pandemic (Mulyaningsih, 2020).

This blended learning design combines the best characteristics of classroom learning. These best characteristics aim to promote active independent learning by students and reduce the amount of faceto-face learning in class. So that blended learning can be a positive means for students to channel their passion for accessing the internet, of course based on the needs of the curriculum by making teachers as facilitators, mediators, and evaluators in managing learning. So that student activities in accessing material in the blended learning-based learning process can be directed and achieve the planned learning objectives (Husamah, 2014).

The advantages of entrepreneurship learning using a blended learning design are the collaboration of various learning strategies with the delivery methods that can optimize the learning experience for students (Purba et al., 2020). Blended learning in entrepreneurship learning is considered to be able to develop innovation abilities, creativity, and adaptability, so that students have high readiness to face learning demands in complex and ill-structured domains (Hidayat, 2018).

The use of blended learning designs in entrepreneurship learning makes students more independent in learning because they can access the learning material on the internet with the 
supervision of parents or older people, whenever and wherever, as long as there is internet access (Suhartono et al., 2019). Students can do research from the web, blogs, e-books, e-libraries, and youtube. Students who have completed their assignment can upload it to the google classroom classwork. The teacher plays a role in providing feedback according to the assessment rubric. The advantage is that the teacher can gets feedback quickly, besides that the skills and creativity of students can increase with the many references to entrepreneurship learning material sources from the internet.

Therefore, by implementing the blended learning design in entrepreneurship learning, it is hoped that it can become an alternative solution for teachers and students to realize learning objectives through the online learning system during the Covid 19 pandemic. On the other hand, teachers and students have also played an active role in supporting government policies to inhibits the spread of Covid 19 in various regions in Indonesia.

\section{RESEARCH METHOD}

The research subjects for the development of this blended learning design were the school principal, entrepreneurship subject teachers, and 29 students of class XII Religion 1 at MA Negeri 1 Magetan. The research subjects were the organizers and implementers of entrepreneurship learning in schools. Development research was used in designing blended learning as an alternative to entrepreneurial learning during the Covid 19 pandemic. Development research aimed to develop blended learning designs in entrepreneurship subjects (Borg \& Gall, 1989). The blended learning design that has been developed was tested for its effectiveness so that it can be implemented in entrepreneurship learning in schools (Sugiono, 2016).
The research model used in designing blended learning in entrepreneurship learning was the ADDIE (Analyze, Design, Development, Implementation, Evaluation) model. The ADDIE model was chosen because it is relevant to the needs and objectives of the blended learning being developed (Aldoobie, 2015). The stages were as follows:

1. Analysis Stage. At this stage the researcher conducted the need analysis for entrepreneurship learning in MAN 1 Magetan, including the learning design used as well as the need analysis of teachers and students for the learning designs developed.

2. Design Stage. At this stage the researcher creates an initial form of entrepreneurial learning design developed after obtained the results of the analysis of the preliminary studies conducted. The next stage, the researcher selected material that is in accordance with the Core Competencies and Basic Competencies in the 2013 Curriculum, so that the development of blended learning can be used in entrepreneurship learning in class XII.

3. Development Stage. At this stage, the researcher developed a blended learning design in the form of an initial draft. To determine the feasibility of the initial draft, a validity test was carried out. The validity test of blended learning is carried out by material experts and media experts, where each expert consists of 2 experts.

4. Implementation Stage. At this stage, the blended learning design that has been validated by experts will be implemented and tested. The trials were carried out three times: small class test, limited class test, and broad class test. This stage was carried out on students who are in class XII MIPA 2. The results obtained in this stage were the feasibility of the blended learning design developed and student learning outcomes 
after working on the evaluation questions contained in the design.

5. Evaluation Stage. At this stage, an evaluation process was carried out on the development of blended learning designs in entrepreneurship learning with the model used. Researchers used formative evaluation to determine the level of validity. The results of the evaluation were used to correct deficiencies, while revisions were used with the aim that the blended learning design can be said feasible and can be used as a source of student learning from the cognitive and affective aspects independently in entrepreneurship learning.

\section{DISCUSSION}

\section{Blended Learning as a Learning Alternative in the Pandemic Era}

During the pandemic era, many online-based learning alternatives can be implemented in the learning process starting from Elementary School to Senior High School. Teachers are required to master various types of learning designs or models that can support the effectiveness and efficiency of learning for their students. This requires teachers to be able to master technology maximally with renewal methods that suit their needs and efforts to realize learning objectives.

However, based on the results of a survey conducted by Syahda Zahra on May 5, 2020, explained that there were $80 \%$ of respondents who indicated that even though various online learning support facilities were available, students tended to think that offline learning was more effective than online learning. This reason is based on the learning process that has been running only using the Zoom Meet or Google Meet application, and the methods used are still conventional (Zahra \& Wijayanti, 2020).
Online learning which tends to be monotonous has various weaknesses including dependence on an internet connection, especially when using Android as a learning operation. So that sometimes causes the network to be unstable and requires a lot of internet quota. On the other hand, conventional learning models actually make students' interest in online learning decrease drastically (Haryanto, 2018).

The main problem of learning in the pandemic era is that the material is not delivered optimally, which causes student competence not to be achieved (Asmuni, 2020). Meanwhile, in more detail the learning problems during the pandemic in Indonesia include students having difficulty understanding the material, difficulties with the workload, the availability and conditions of the internet network, students' low mastery of technology, and the increasing level of student boredom (Putro et al., 2020).

These problems require a learning design that does not only focus on one application with conventional methods or students listen to the teacher then repeat what has been explained. This model must be eliminated immediately because it will increase the problems and learning load of students during the pandemic. Blended learning design can be an alternative solution in increasing student interest in learning and increasing the effectiveness and efficiency of learning.

Blended learning design is a new innovation in responding to the challenges of the times. Blended learning is a mixture of conventional learning models which carried out face-to-face meet with internetbased learning models and technology (Hamzah, 2011). This learning model is an inexpensive and effective way of learning, because it can be applied to students at various levels of education, especially as an effort to support the government in preventing 
the spread of the Covid 19 virus in educational institutions (Suyono \& Hariyanto, 2011). On the other hand, the blended learning design during the pandemic made it easier for students because students could study anywhere and anytime without waiting for learning in class (Purnomo et al., 2016).

Broadly speaking, the blended learning design as an alternative to learning has several objectives such as helping students develop themselves through a learning process that is in accordance with their learning style; provide practical and realistic opportunities for teachers and students to undertake independent, useful and growing learning; and overcoming the learning problems that require completing tasks using a variety of learning (Budiarto, 2016).

There are several advantages of the learning process when using a blended learning design, there are: students are more motivated to learn because it is supported by a variety of media, can increase students' activity and involvement because it uses interactive media, the internet can visualize the complex models, the learning process goes beyond time, and can display creative, interactive, and innovative learning design (Yasa, 2017).

Through blended learning for the learning in the pandemic era, it is hoped that it will be able to minimize various problems that have occurred in the learning process. Because effective learning is learning that can optimally utilize information and communication technology as a tool (Ismawati \& Prasetyo, 2020). On the other hand, the selection of internet-based technology learning media for students must indeed be considered, because if this is not appropriate it can have a negative impact on students, especially in the pandemic era. Because basically a teacher must be able to understand the principles and factors that can influence the effectiveness of digital technology in the learning process at the high school level (Putrawangsa, 2018).

\section{Blended Learning Design in Entrepreneurship Learning}

\section{Analysis}

Based on the results of interviews and observations, entrepreneurial learning designs in MAN 1 Magetan have never used technology-based learning designs. Teachers only used conventional methods in the learning process, so students think that entrepreneurship learning is less interesting and boring. In fact, entrepreneurship learning should provide opportunities for students to be active and able to innovate by building their own knowledge and abilities. According to (Winkel, 2012), learning is a mental activity that cannot be witnessed only from the outside, what happens inside a person who is learning cannot be known directly by just observing that person, in this case the teacher.

Various difficulties experienced by students in learning entrepreneurship are due to the delivery of material that is sometimes unclear, less innovative and too fast, so that it has an impact on students who have difficulty understanding the material. So it can be concluded that; (1) entrepreneurship learning only refers to one textbook without any new innovations that teachers and students can use; (2) not maximizing the supporting facilities during the learning process in the classroom; (3) teachers teach using conventional methods; (4) the target of completing the material in the textbook does not match the learning objectives. Based on the needs analysis, MAN 1 Magetan requires new innovations in the entrepreneurial learning process, especially which are in accordance with the development of science and technology. Creating technology-based learning designs in entrepreneurship learning can be done by looking at the syllabus of entrepreneurship 
subjects in the 2013 Curriculum, so that the determination of material, Core Competencies and Basic Competencies are in accordance with entrepreneurship learning at schools.

\section{Design}

The first design is carried out by selecting materials which are in accordance with the Basic Competencies in the syllabus of Entrepreneurship in the 2013 Curriculum.The next stage determined the blended learning design format according to the Directorate General of Teachers and Education Personnel published by the ministry of education and culture (2016) and The learning design format according to (Prastowo, 2013) was modified by the researcher.

The blended learning design in entrepreneurship subjects consists of: cover/preliminaries; the title of the application, namely Workshops and Entrepreneurship (Prakarya dan Kewirausahaan), then in the Matter Text section there is an introduction which contains an introduction, instructions for use, Core Competencies and Basic Competencies, learning objectives, indicators of success and bibliography; The content of the learning design consists of a concept map, Sub-chapter 1 Ideas and Opportunities for Regional Typical Food Businesses which are Modified from Vegetable and Animal Materials, Sub-chapter 2 Material Processing, Regional Typical Food Businesses which are Modified from Vegetable and Animal Materials, Sub-chapter 3 Business Marketing Regional Typical Food Modified from Vegetable and Animal Materials, Sub-chapter 4 Regional Typical Food Administration Modified from Vegetable and Animal Materials, Sub-chapter 5 Consignment Sales System for Regional Typical Food Businesses Modified from Vegetable and Animal Materials, which in each sub-chapter there is a summary of the material, a video and in the end of the discussion there is a group assignment; The last/postliminary section contain 20 multiple choice evaluation questions and the author's bio.

\section{Development}

The blended learning design that has been developed was tested for its feasibility in terms of material and media before being implemented in entrepreneurship learning in schools. First, there were 10 assessment indicators using a Likers scale on the developed digital media. Scale 3 got scale value of 1 voter, so the value for the selected scale was $1 \times 3=3$, so the total score for scale 3 is 3 . Meanwhile, scale 4 got a scale value of 8 voters, so the value for the selected scale was $8 \times 4=32$, so the total score on scale 4 is 32 . Meanwhile, scale 5 got a scale value of 11 voters, so the value for the selected scale was $11 \times 5=55$, so the total score on a scale of 5 is 55 . The total number was obtained based on the sum of the scale values 1 X $3=$ 3 , the sum of scale values $8 \times 4=32$, and the sum of the scale value $11 \times 5=55$. The average value of the material expert's validation can be seen from the results of mathematical calculations between the number of questions divided by the number indicator items by two validators, there was 90: $20=4.50$. Based on the results of the validation that has been done by the media expert validator, the learning design product developed got score of 4.50 which was included in very good category. The conclusion that can be drawn from the description above is that the blended learning design was feasible to be tested. As for the suggestions from the validator, improvements in the learning design of navigation can be clarified, additions to the bibliography, and it would be better if given additional videos and voice recordings.

Second, there were 4 assessment components consisting of format, language, illustrations, and content with a total of 19 indicators in the material expert validation sheet. Scale 4 got a scale value of 15 voters, so the value for the selected scale was $15 \mathrm{X} 4=$ 60 , so the total score for scale 4 was 60 . Meanwhile, 
scale 5 got a scale value of 23 voters, so the value for the selected scale was $23 \times 5=115$, so the total score on a scale of 5 was 115 . The total number was obtained based on the sum of scale values $15 \mathrm{X} 4$, and the sum of scale values $23 \times 5$. The average value of the material expert validation can be seen from the results of mathematical calculations between the number of questions divided by the number of indicator items by two validators, there was 175: $38=$ 4.60. Based on the results of the validation that has been carried out by the expert material validators, the material in the learning design developed got a value of 4.60 which is included in the very good category. The conclusion that can be drawn from the description above is that entrepreneurship learning materials developed through entrepreneurship learning designs were feasible to be tested.

\section{Implementation}

The implementation stage of the blended learning learning design was carried out 3 times starting from small class trials, limited class trials and broad class trials. Limited class trials were implemented in class XII MIPA 2 with 10 students randomly selected. Students got a questionnaire sheet which contains a feasibility assessment of the blended learning design and ended up working on evaluation questions. It aimed to determine student responses to blended learning design in entrepreneurship subjects. The questionnaire used a Likers scale consisting of design interest, material in blended learning design, and the use of language in blended learning design. At the implementation stage in small classes, the feasibility of the product got a score of 225 with a mean of 3.5 so that the learning design was in the sufficient category. Meanwhile, student learning outcomes in limited classes got an average value of 70.5 with the explanation that 3 students were unable to achieve the minimum completeness criteria and 7 other students were able to achieve the minimum completeness criteria. Meanwhile, in the broad class trial conducted on 16 students in class XII MIPA 2, they got a total score of 797 with a mean of 3.8 so that the teaching materials were in the sufficient category. Meanwhile, the learning outcomes in the broad class showed that the mean posttest score of students was 52.8 with the lowest score of 20 and the highest score of 100 .

Meanwhile, to determine the increase in students' knowledge after receiving treatment, a test was carried out using SPSS 20.The tests carried out included: normality test, homogeneity test, and paired sample $t$ test with the aim of testing the average difference between two groups of paired data (Priyatno, 2014). This test is useful in assessing the effectiveness of blended learning design. Based on the tests that have been carried out, it shows the learning outcome data before and after the treatment was normally distributed and homogeneous. Different test results using paired sample $t$ test can be seen that the sig. equal to $0.00(<0.05)$, so that $\mathrm{HO}$ was rejected, which means there was a difference in the mean score of students before and after treatment. The difficulties experienced by students were still struggling with the implementation of learning during the Covid 19 pandemic, especially in entrepreneurship learning, considering besides having to understand the theory, students must also carry out practice. However, with the existence of this blended learning design, students are able to carry out entrepreneurial learning even with a limited time.

\section{Evaluation}

The evaluation stage was carried out by assessing the blended learning design in entrepreneurship learning developed, as well as evaluations which were carried out sequentially starting from the initial stage, the analysis, to the final stage, the final evaluation. Each evaluation was revised with the aim of producing a blended learning design that is perfect and in 
accordance with the applicable educational standards. The blended learning designs in entrepreneurship learning that have been validated and implemented in either limited class trials or broad class trials, in every validation and trial that has been carried out, the design got an assessment and suggestions for revision until it becomes the final draft of the developed design. So that it can be declared feasible and used as an alternative in entrepreneurship learning at MAN 1 Magetan.

\section{IV.CONCLUSION}

The main problem of catching up in the pandemic era is that the material is not delivered optimally which causes student competence to be not achieved. Blended learning design is a new innovation in responding to the challenges of the times. Blended learning is a mixture of conventional learning models which carried out by face-to-face meet with internetbased learning models and technology. This blended learning design combines the best characteristics of classroom learning, through these best characteristics aims to improve active independent learning by students and reduce the amount of face-to-face time in class. The use of blended learning designs in entrepreneurship learning makes students more independent in learning because they can access material contained on the internet with the supervision of parents or older people, whenever and wherever, as long as there is internet access.

\section{REFERENCES}

[1]. Aldoobie, N. (2015). ADDIE Model. American International Journal of Contemporary Research, 5(6), 68-72.

[2]. Anugrahana, A. (2020). Hambatan, Solusi dan Harapan: Pembelajaran Daring Selama Masa Pandemi Covid-19 Oleh Guru Sekolah Dasar. Scholaria: Jurnal Pendidikan Dan Kebudayaan,
10(3),

282-289.

https://doi.org/10.24246/j.js.2020.v10.i3.p282-

289

[3]. Asmuni, A. (2020). Problematika Pembelajaran Daring di Masa Pandemi Covid-19 dan Solusi Pemecahannya. Jurnal Paedagogy, 7(4), 281. https://doi.org/10.33394/jp.v7i4.2941

[4]. Borg, W., \& Gall, M. (1989). Education Research, An Introduction Fifth Edition. New York: Longman.

[5]. Budiarto, T. (2016). Blended Learning Di Perguruan Tinggi Di Tinjau Dari Perspektif Leadership Dan Iklim Organisasi. UPI Bandung.

http://repository.upi.edu/id/eprint/23938

[6]. Hamzah, U. (2011). Model Pembelajaran. Bumi Aksara.

[7]. Haryanto, S. (2018). Kelebihan Dan Kekurangan E-Learning Berbasis Schoology. Prosiding Seminar Nasional Geotik, 2016, 106110.

[8]. Hidayat, R. (2018). Game-Based Learning: Academic Games sebagai Metode Penunjang Pembelajaran Kewirausahaan. Buletin Psikologi, 26(2), 71. https://doi.org/10.22146/buletinpsikologi.30988

[9]. Husamah. (2014). Pembelajaran Bauran (Blended Learning). Jakarta: Prestasi Pustaka Raya.

[10]. Ismawati, D., \& Prasetyo, I. (2020). Efektivitas Pembelajaran Menggunakan Video Zoom Cloud Meeting pada Anak Usia Dini Era Pandemi Covid-19. Jurnal Obsesi: Jurnal Pendidikan Anak Usia Dini, 5(1), 665. https://doi.org/10.31004/obsesi.v5i1.671

[11]. Jailani, H., Fahrurrozi, M., \& Rizqi, Y. A. (2017). Pengaruh Pembelajaran Kewirausahaan terhadap Minat dan Motivasi Berwirausaha Siswa di SMK Negeri 1 Selong Tahun Pelajaran 2016. Jpek, 1(1), 49-56. 
[12]. Mulyaningsih, W. (2020). Belajar IPA Sistem Blended Learning Pasca Pandemi Covid19 (pp. 1-900).

https://radarsemarang.jawapos.com/rubrik/unt ukmu-guruku/2020/05/27/belajar-ipa-sistem-

blended-learning-pasca-pandemi-covid-19/

[13]. Prastowo, A. (2013). Panduan Kreatif Membuat Bahan Ajar Inovatif. Diva Press.

[14]. Priyatno, D. (2014). SPSS 22 Pengolahan Data Terpraktis. CV Andi Offset.

[15]. Purba, M., Heinzhe, A., \& Procther, C. (2020). Pembelajaran Sejarah Harus Lebih Kreatif di Tengah Pandemi. https://guruberbagi.kemdikbud.go.id/artikel/pe mbelajaran-kreatif-di-tengah-pandemi/

[16]. Purnomo, A., Ratnawati, N., \& Aristin, N. F. (2016). Pengembangan Pembelajaran Blended Learning Pada Generasi Z. Jurnal Teori Dan Praksis Pembelajaran IPS, 1(1), 70-76. https://doi.org/10.17977/um022v1i12016p070

[17]. Putrawangsa, S. (2018). Desain Pembelajaran: Design Research sebagai Pendekatan Desain Pembelajaran. Mataram: CV. Reka Karya Amerta.

[18]. Putro, S. T., Widyastuti, M., \& Hastuti. (2020). Problematika pembelajaran di era pandemi covid-19 studi kasus: Indonesia, Filipina, Nigeria, Ethipoia, Finlandia, dan Jerman. 18(2).

[19]. Sugiono. (2016). Metode Penelitian Pendidikan: Pendekatan Kuantitatif, Kualitatif dan R\&D. Bandung : Alfabeta.

[20]. Suhartono, Jamaludin, \& Sumiyati, S. (2019). Training on the Blended Learning Design As a Supplement To a Learning Approach At Primary Schools. Diseminasi: Jurnal Pengabdian Kepada Masyarakat, 1(1), 16-23. https://doi.org/10.33830/diseminasiabdimas.v1i 1.501

[21]. Suyono, \& Hariyanto. (2011). Belajar dan Pembelajaran. Rosdakarya.
[22]. Winkel. (2012). Roles Of Teachers and Learners. Oxford University.

[23]. Yasa, S. (2017). Kajian Model Pembelajaran Blended Learning. https://sukeratayasa.wordpress.com/kajianmodel-pembelajaran-blended-learning/

[24]. Zahra, A. S., \& Wijayanti, S. (2020). Efektivitas Pembelajaran Basis Online Di IAIN Tulungagung Dengan Adanya Kebijakan Physical Distancing Era Pandemi Covid 19. Geram (Gerakan Aktif Menulis). Malaysian Palm Oil Council (MPOC), 21(1), 1-9. http://mpoc.org.my/malaysian-palm-oilindustry

\section{Cite this article as :}

Qurota Yunus Syafidah, Trisno Martono, Khresna Bayu Sangka, "Blended Learning as An Alternative of Entrepreneurship Learning Design in The Period of Covid 19 Pandemic", International Journal of Scientific Research in Computer Science, Engineering and Information Technology (IJSRCSEIT), ISSN : 2456-3307, Volume 7 Issue 2, pp. 15-23, March-April 2021.

Available at

doi : https://doi.org/10.32628/CSEIT217154

Journal URL : https://ijsrcseit.com/CSEIT217154 